\title{
Model Determinan Stock Prices Perusahaan Sub Sektor Kesehatan dan Farmasi di Bursa Efek Indonesia
}

\author{
Suyono $^{\left.1^{*}\right)}$, Peri Akri \\ $\left.1^{*}, 2\right)$ Institut Bisnis dan Teknologi Pelita Indonesia \\ Jl. A Yani No. 78-88 No. Telp (0761) 24418 Pekanbaru 28127 \\ E-mail: suyono@lecturer.pelitaindonesia.ac.id ${ }^{1 *}$
}

\begin{abstract}
ABSTRAK
Penelitian ini bertujuan untuk menguji dan menganalisis determinan rasio DER, ROE, PER, EPS, and PBV terhadap return Saham perusahaan perusahaan subsektor kesehatan dan farmasi yang terdaftar dibursa efek Indonesia selama periode tersebut. Data Populasi yang digunakan dalam penelitian ini yaitu seluruh perusahaan sub sektor kesehatan dan farmasi yang ada di BEI tahun selama 20122019 sebanyak 12 perusahaan. Sedangkan teknik pengambilan sampel dengan menggunakan metode purposive sampling, sehingga sampel diperoleh 8 perusahaan sampel. Teknik analisis data dalam penelitian digunakan regression PLS dengan bantuan softare Smart PLS, karena data tidak berdistribusi normal. Hasil penelitian menunjukan rasio DER dan ROE mempunyai pengaruh signifikan negatif terhadap return saham. Sedangkan rasio PER, EPS dan PBV tidak signifikan terhadap return saham perusahaan subsektor kesehatan dan farmasi yang terdaftar dibursa efek Indonesia selama 2012-2019. Return saham dipengaruhi oleh faktor DER, EPS, PBV, PER, ROE sebesar $27,8 \%$, sedangkan sisanya $72.2 \%$ dipengaruhi oleh faktor lain yang tidak diuji dalam model penelitan ini misalnya baik faktor intern maupun faktor eksternal.
\end{abstract}

Kata Kunci: Debt to Equity; Earning Per Share; Price Earning Ratio; Price Book Value; Return On Equity; Stock Prices

\begin{abstract}
This study aims to discuss and analyze the ratio of DER, ROE, PER, EPS, and PBV to the stock returns of health and pharmaceutical subsector companies listed in the Indonesian stock exchange during that period. Population data used in this study in all health and pharmaceutical sub-sector companies on the Indonesia Stock Exchange in 2012-2019 were 12 companies. While the sampling technique uses purposive sampling method, so that the sample is obtained by 8 sample companies. Data analysis techniques in this study used PLS regression with the help of Smart PLS softare, because the data were not normally distributed. The results showed the ratio of DER and ROE had a significant negative effect on stock returns. While the PER, EPS and PBV ratios are not significant to the company's stock returns. Stock returns by the DER, EPS, PBV, PER, ROE factors of $27.8 \%$, while the remaining $72.2 \%$ are approved by other factors not taken in this research model such as internal factors or external factors.
\end{abstract}

Keywords: Debt to Equity; Earning Per Share; Price Earning Ratio; Price Book Value; Return On Equity; Stock Prices

\section{PENDAHULUAN}

Meningkatnya kebutuhan masyarakat didalam sektor kesehatan dan farmasi memberikan peluang bagi para investor untuk menanamkan sebagian modalnya. Sektor ini 
sangat menjajikan dalam keputusan berinvestasi, kerena sektor ini merupakan sektor yang banyak dibutuhkan dan diminati banyak orang. Jika mengacu pada angka Indeks Pertumbuhan penduduk di Indonesia beberapa tahun terakhir mengalami trend meningkat (Badan Pusat statistik). Tentunya sektor ini mempunyai peran penting baik bagi masyarakat maupun bagi negara. Jika tercermin pada indeks harga saham sektoral perusahaan subsektor kesehatan dan farmasi selama 2012-2019 perusahaan mengalami fluktuatif.

Kodisi yang berbeda yang terjadi pada indeks harga saham gabungan justru tidak stabil, dimana IHSG mengalami pergerakan fluktuasi. Dimana naik turunnya harga saham dikarenakan oleh beberapa faktor, oleh karena itu untuk mengambil suatu keputusan, investor perlu memiliki data dan informasi yang lengkap dan akurat. Data yang diperlukan diantarnya Laporan Keuangan suatu perusahaan. Jika tercermin dari indeks harga saham sektoral pada perusahaan subsektor kesehatan dan farmasi selama 2012 sampai dengan 2019. Banyak faktor yang menyebabkan fluktuatif harga saham perusahaan kesehatan dan farmasi yang terdaftar BEI selama 2012-2019 diantaranya :

Faktor DER ini penting bagi perusahaan untuk melihat sejauh mana perusahaan dapat melunasi hutangnya dengan modalnya, dimana semakin tinggi rasio ini maka semakin beresiko terhada kinerja keuangan perusahaan, sebaliknya. Rasio DER mempunyai hubungan terhadap Return saham perusahan dimana semakin kecil DER yang dimiliki perusahaan maka semakin tinggi pula return saham perusahaan begitu juga sebaliknya. Penelitian yang berhubungan dengan pengaruh DER terhadap return saham dimana dilakukan Haryanti \& Murtiasih (2019), Amanda et al (2013) dan Akbar (2015) menyatakan bahwa DER signifikan Negatif Terhadap return saham. Penelitian yang dilakukan oleh Suharno. (2016), Pratiwi et al. (2016), dan Herawati \& Putra (2018) hasil penelitiannya menunjukan DER signifikan positif Terhadap return saham. Berbeda dengan hasil penelitian yang dilakukan oleh Nurfadillah (2011) dan Utami\& Darmawan (2019) hasil penelitiannya justru DER tidak signifikan Terhadap return saham

Faktor ROE penting bagi perusahaan untuk menghasilkan laba perusahaan, ROE mempunyai hubungan positif terhadap return saham perusahaan, jika ROE perusahaan meningkat maka return saham perusahaan juga ikut meningkat. Penelitan yang berhubungan dengan ROE terhadap return saham dimana dilakukan oleh Nurfadillah (2011), Amanda (2013), Smith dan, \& Azis (2016) serta Cahyaningrum \& Antikasari (2017) hasil penelitiannya menyatakan ROE signifikan positif terhadap return saham. sedangkan penelitian yang dilakukan oleh Pratiwi et al. (2016), Utami \& Darmawan (2019) serta Arslan \& Zaman (2014) justru ROE tidak signifikan terhadap return saham. 
Faktor PER mempunyai peran penting bagi perusahaan untuk meningkatkan kinerja keuangan perusahaan. Price Earning Ratio yang tinggi menunjukkan bahwa investor bersedia untuk membayar dengan harga saham premium untuk perusahaan. PER mempunyai hubungan positif terhdap return perusahaan, PER yang tinggi juga akan meningkatkan return saham perusahaan. Beberapa penelitian tentang PER terhadap return saham yaitu penelitian yang dilakukan Suharno (2016), Herawati \& Putra (2018), serta Imran \& Shahzad (2014) hasil penelitiannya menyatakan bahwa PER signifikan positif terhadap return saham. Sedangkan penelitian yang dilakukan oleh Amanda et al. (2013) dan Akbar, R. (2015) sebaliknya PER tidak signifikan terhadap return saham.

Faktor EPS digunakan oleh perusahaan untuk menggambarkan jumlah rupiah yang diperoleh untuk setiap lembar saham biasa. EPS mempunyai hubungan positif terhadap return saham perusahaan. Jika EPS perusahaan meningkat maka Return saham juga ikut meningkat. Penelitian yang berhungan dengan EPS terhadap return saham Nurfadillah (2011), Pratiwi et al. (2016), Amanda et al. (2013), Utami \& Darmawan (2019), Haryanti \& Murtiasih (2019), Arslan\& Zaman (2014) serta Cahyaningrum\& Antikasari (2017) hasil penelitiannya menyatakan PER signifikan positif terhadap return saham. Penelitian yang dilakukan oleh Ahmed, I (2018) EPS tidak signifikan terhadap return saham.

Faktor PBV penting bagi perusahaan untuk mengambarkan kepercayaan pasar dalam perkembangan perusahaan. PBV menunjukan seberapa jauh perusahaan mempu menciptakan nilai perusahaan rrelatif terhadap jumlah modal yang diinvestasikan. PBV mempunyai hubungan positif terhadap return saham, dimana semakin besar nilai PBV maka akan semakin tinggi nilai saham perusahaan. Penelitian tentang pengaruh PBV terhadap return saham dimana dilakukan oleh Cahyaningrum \& Antikasari (2017) menyatakan PBV berpengaruh positif terhdap return saham. Penelitian yang dilakukan oleh Benazir (2016) PBV signifikan negatif terhadap return saham. Berbeda lagi dengan penelitian yang dilakukan Akbar (2015) PBV tidak signifikan terhadap return saham.

Keunikan penelitian ini dapat diperlihatkan dimana kondisi harga saham perusahaan subsektor kesehatan dan farmasi dalam keadaan tidak stabil, selain itu periode pengamatan yang dilakukan dalam rentang waktu 2012-2019. Penelitian ini perlu dilakukan karena rasa ingin tahu faktor yang dominan dalam mempengaruhi naik turunnya harga saham perusahaan. Selain itu ditemukan adanya perbedaan atau riset gap terhadap hasil penelitian yang dilakukan sebelumnya. Dengan demikian maka perlu dilakukan lebih lanjut melakukan pengkajian tentang faktor-faktor yang mempengaruhi return saham pada perusahan subsektor kesehatan dan farmasi selama 2012-2019 
Berdasarkan latar belakang masalah tersebut dapat diketahui apa yang menjadi tujuan dalam penelitian yaitu untuk mengetahui dan menganalisis pengaruh Debt To Equity Ratio (DER), Return On Equity (ROE), Price Earning Ratio (PER), Earning Per Share (EPS), Price Book Value (PBV) terhadap harga saham pada perusahaan sub sektor Kesehatan dan Farmasi yang terdaftar di Bursa Efek Indonesia (BEI) selama periode 2012 sampai dengan 2019.

Ross et.al mengungkapkan bahwa return saham yaitu selisih dari harga saham pada penutupan akhir tahun tertentu dengan harga saham penutupan pada akhir tahun sebelumnya. Harga saham yang tinggi menandakan kinerja perusahaan semakin baik. Saham yang tinggi dapat memberikan patokan kepada investor dalam pengambilan keputusan investasi. Return saham dapat dihitung dengan rumus:

Harga Saham Thn Sekarang - Harga Saham Thn

Return Saham (RS) $=\frac{\text { Sebelumnnya }}{\text { Harga Saham Thn Sebelumnnya }}$

Rasio utang terhadap ekuitas (Debt to equity ratio) merupakan rasio yang mengukur sejauh mana besarnya utang dapat ditutupi oleh modal sendiri. Debt equity ratio atau sering disebut dengan DER yang merupakan kemampuan perusahan dalam memenuhi keajiban atau hutang dengan modal yang dimiliki oleh perusahaan. Rasio ini mengukur persentase penggunaan dana yang berasal dari kreditur. Menurut Widayanti (2009), Kreditur lebih menyenangi rasio hutang yang rendah, karena semakin rendah ratio hutang semakin besar perlindungan yang diperoleh kreditur. DER mempunyai peran peting bagi perusahaan, dimana semakin tinggi nilai DER maka kinerja keuangan perusahaan akan semakin rendah, sebalik jika DER yang dimiliki suatu perusahaan rendah makan dapat di nilai kinejra keuangan perusahaan semakin baik. DER mempunyai hubungan negatif terhadap Return saham, dimana tingginya nilai DER akan mengakibatan turunnya nilai saham perusahaan. Hal ini didukung dengan hasil penelitian yang dilakukan oleh Haryanti \& Murtiasih (2019), Amanda et al. (2013) dan Akbar (2015).

Rasio ini dapat dihitung mengunakan formulasi sebagai berikut :

$$
\text { Debt Equity Ratio (DER) }=\frac{\text { Total Debt }}{\text { Total Equity }}
$$


Return on Equity atau sering diistilahkan dengan singkatan ROE. Rasio ini merupakan bagian dari rasio profitabilitas. Rasio mempunyai peran penting bagi perusahaan sebagai menghasil laba dengan menggunkan equitynya. Nilai ROE yang tinggi berarti kinerja keuangan perusahaan juga semakin tinggi, sebaliknya jika ROE perusahaan rendah makan juga dapat menurunkan keuangan perusahaan. Return On Equity (ROE) salah satu rasio profitabilitas yang digunakan untuk mengukur tingkat efektivitas perusahaan dalam menghasilkan keuntungan dengan memanfaatkan ekuitas. Syamsuddin (2011) menyatakan bahwa return on equity merupakan suatu pengukuran dari pendapatan atas modal yang diinvestasikan dalam perusahaan. Semakin besar rasio ROE menggambarkan semakin baik keadaan perusahaan, sehingga akan meningkatkan kepercayaan investor untuk menanamkan modalnya. ROE mempunyai hubungan atau pengaruh yang positif terhadap return saham perusahaan, berarti ROE yang tinggi juga akan mengakibatkan peningkatan return saham. Pernyataan ini didukung dengan hasil penelitian yang dilakukan Nurfadillah (2011), Amanda et al. (2013), Smith \& Azis (2016) serta Cahyaningrum\& Antikasari (2017).

Return on equity dapat diformulasikan :

$$
\mathrm{ROE}=\frac{\mathrm{EAT}}{\text { Equity }}
$$

Price Erning Ratio atau disingkat dengan PER. Rasio PER merupakan perbandingan antara harga perlembar saham dengan jumlah saham yang beredar. PER mempunyai peran penting bagi perusahaan, karena mempunyai hubungan yang erat terhadap harga saham. Jika nilai PER yang tinggi maka harga saham perusahaan juga akan semakin tinggi. Hal ini didukung oleh penelitian Suharno (2016), Herawati \& Putra (2018), serta Imran \& Shahzad(2014). PER dapat di formulasikan sebagai berikut :

$$
\text { PER }=\frac{\text { Harga per Lembar Saham }}{\text { Laba per Lembar Saham ) }}
$$

Earning Per Share (EPS) digunakan oleh perusahaan untuk mendeskripsikan jumlah rupiah yang didapat untuk setiap lembar saham biasa. Menurut Karnadjaja (2009), EPS saat ini dibandingkan dengan nilai EPS tahun sebelumnya pada kuartal yang sama untuk mengetahui pertumbuhan keuntungan perusahaan. Semakin tinggi laba bersih yang diperoleh perusahaan maka semakin tinggi pula nilai EPS. Semakin tinggi EPS maka akan semakin mahal suatu saham, karena EPS merupakan salah satu bentuk rasio keuangan untuk menilai kinerja perusahaan. Dengan demikian bila seorang investor ingin meraih keuntungan maka investor perlu memahami keadaan keuangan yang disajikan dalam bentuk laporan keuangan 
suatu perusahaan. EPS mempunyai hubungan positif terhadap return saham perusahaan. Jika EPS perusahaan meningkat maka Return saham juga ikut meningkat. Hal didukung dengan hasil penelitian Nurfadillah (2011), Pratiwi et al. (2016), Amanda et al. (2013), Utami \& Darmawan (2019), Haryanti \& Murtiasih (2019), Arslan \& Zaman, (2014) serta Cahyaningrum \& Antikasari (2017). Rasio EPS dapat diformulasikan:

$$
\text { EPS }=\frac{\text { Laba Bersih Setelah Pajak }}{\text { Jumlah Saham yang Beredar }}
$$

Anthanasius (2012) mengatakan rasio PBV yaitu rasio yang dapat mengambarkan seberapa besar suatu saham untuk dibeli oleh investor dengan membandingkan nilai buku saham yang ada. Dimana semakin kecil PBV maka harga saham suatu perusahaan akan semakin rendah harganya. Price Book Value (PBV) menunjukan seberapa jauh perusahaan mempu menciptakan nilai perusahaan rrelatif terhadap jumlah modal yang diinvestasikan. PBV mempunyai hubungan positif terhadap return saham, dimana semakin besar nilai PBV maka akan semakin tinggi nilai saham perusahaan.penelitian tentang pengaruh PBV terhadap return saham dimana dilakukan oleh Cahyaningrum \& Antikasari (2017) hasil penelitiannya juga menyatakan PBV signifikan positif terdahap return saham perusahaan. Price Book Value dapat diukur menggunakan formulasi:

$$
\mathrm{PBV}=\frac{\text { Harga per Lembar Saham }}{\text { Nilai Buku per Lembar Saham }}
$$

\section{KERANGKA PEMIKIRAN}

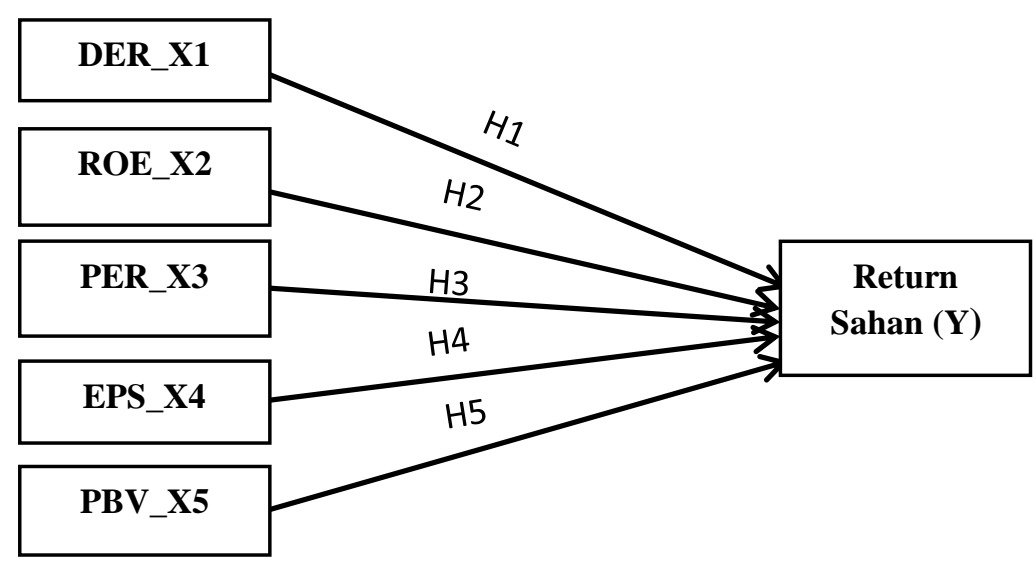

Gambar 1. Model Penelitian

Sumber : Jurnal Penelitian dikembangkan, 2020 
Berdasarkan kerangka pemikiran tersebut, maka dapat dibuat suatu hipotesis dalam penelitian ini sebagai berikut:

Hipotesis 1: Terdapat pengaruh signifikan DER terhadap Return Saham perusahaan kesehatan dan farmasi yang terdaftar di Bursa Efek Indonesia selama periode pengamatan 2012-2019.

Hipotesis 2: Terdapat pengaruh signifikan ROE terhadap Return Saham perusahaan kesehatan dan farmasi yang terdaftar di Bursa Efek Indonesia selama periode pengamatan 2012-2019.

Hipotesis 3: Terdapat pengaruh signifikan PER terhadap Return Saham perusahaan kesehatan dan farmasi yang terdaftar di Bursa Efek Indonesia selama periode pengamatan 2012-2019.

Hipotesis 4: Terdapat pengaruh signifikan EPS terhadap Return Saham perusahaan kesehatan dan farmasi yang terdaftar di Bursa Efek Indonesia selama periode pengamatan 2012-2019.

Hipotesis 5: Terdapat pengaruh signifikan PBV terhadap Return Saham perusahaan kesehatan dan farmasi yang terdaftar di Bursa Efek Indonesia selama periode pengamatan 2012-2019.

\section{METODE PENELITIAN}

Penelitian ini dilakukan pada perusahaan Sub Sektor Kesehatan Dan Farmasi Di Bursa Efek Indonesia dengan rentang waktu selama 2012 sampai dengan 2019. Penelitian ini dilakukan mulai dari pengarujuan PDP tahun 2019 sampai dengan tahun pelaksanaan penelitian 2020 .

Populasi dalam penelitian ini 12 perusahaan Sub Sektor Kesehatan Dan Farmasi Di BEI periode 2012-2019. Sedangkan proses penarikan sampel menggunakan metode Purposive Sampling. Adapun kriteria dalam penelitian yang digunakan yaitu (1) Perusahaan kesehatan dan farmasi yang memiliki Laporan Keuangan secara lengkap selama periode pengamatan (3) Perusahaan tidak delisting dan merger. Berdasarkan kriteria sampel tersebut, maka terdapat 8 perusahaan yang sesuai dengan kriteria sampel. Adapun daftar perusahan sampel penelitian periode 2012- 2019 sebagai berikut: 
Tabel 1. Perusahaan Sampel

\begin{tabular}{cclc}
\hline No & Kode & \multicolumn{1}{c}{ Nama Perusahaan } & Tanggal IPO \\
\hline 1 & DVLA & Darya Varia Laboratoria Tbk & 11Nopember 1994 \\
\hline 2 & INAF & Indofarma (Persero) & 17 April 2001 \\
\hline 3 & KAEF & Kimia Farma (Persero) Tbk & 04 Juli 2001 \\
\hline 4 & KLBF & Kalbe Farma Tbk & 30 Juli 1991 \\
\hline 5 & MERK & Merk Indonesia Tbk & 23 Juli1981 \\
\hline 6 & PYFA & Pryidam Farma Tbk & 16Oktober 2001 \\
\hline 7 & SCPI & Merk SDP Tbk (Schering Plough Indonesia) & 08 Juni 1990 \\
\hline 8 & TSPC & Tempo Scan Pasific Tbk & 17 Januari 1994 \\
\hline
\end{tabular}

Sumber : www.idx.co.id

Teknik pengumpulan data dengan cara mengunjungi website pasar modal yang ada di bursa efek Indonesia diantaranya situs www.idx.co.id, www.sahamok.com, www.yahoofinance.com. Teknik pengumpulan data selanjutnya melalui Studi keperpustakaan dengan cara membacara dan mengutip buku-buku, jurnal, artikel, media masa, dan jurnal terdahulu yang berhubungan dengan penelitian yang dilakukan.

Teknik Analisa Data yang digunakan adalah Analisis deskriptif tentang nilai rata-rata, nilai tertinggi, nilai minimum dan simpangan baku dari data penelitian yang telah dilakukan. Uji Multikolinieritas data adalah uji yang bertujuan untuk melihat apakah model regresi yang digunakan dalam penelitian terdapat hubungan antar variabel bebas atau tidak. Jika terjadi ada hubungan antar variabel bebas maka sebaiknya dikeluarkan dari model regresi. Untuk mendeteksi ini hasil uji ini dengan menggunakan smart PLS dengan melihat hasil collinearity statistics dengan melihat nilai VIF kecil dari 10. Uji Model adalah uji agar dapat mendeteksi melihat hasil uji koefisien determinasi R2. Karena variabel dalam penelitian ini lebih dari 2 variabel bebas, maka untuk mendeteksi kontribusi variabel bebas terhadap variabel terikatnya dengan cara melihat nilai Adj R2. Semakin tinggi nilai ADJ R2 maka semakin baik model penelitian yang dihasilkan.

Analisis regresi dalam penelitian ini digunakan Regresi PLS memakai software Smart PLS, sehingga dalam analisis ini dapat dibuat persamaan yaitu:

$$
\mathbf{Y}=\boldsymbol{\beta}_{1} \mathbf{X}_{1}+\beta_{2} \mathbf{X}_{2}+\beta_{3} \mathbf{X}_{3}+\beta_{4} X_{4}+\beta_{5} X_{5}+e
$$

Keterangan:

$\beta_{1-} \beta_{5}=$ Koefisien Regresi Masing-masing Variabel

$\mathrm{Y} \quad=$ Return Saham_Y1

$\mathrm{X}_{1}=D E R \_X 1$

$\mathrm{X}_{2}=R O E \_\mathrm{X} 2$

$\mathrm{X}_{3}=P E R \_X 3$

$\mathrm{X}_{4}=E P S \_X 4$ 
$\mathrm{X}_{5}=P B V_{-} X 5$

$\mathrm{e} \quad=$ Variabel Penganggu

Untuk menguji hipotesis yang digunakan dalam penelitian ini adalah signifikansi pada analisis regresi pls. Uji hipotesis yang dimaksudkan yaitu melihat pengaruh antara variabel independent terhadap variabel dependent-nya. Adapun kriteria pengujian pada uji signifikansi penelitian ini, dimana dengan melihhat nilai signifikansi tersebut terhadap nilai alpha. Jika nilai signifikansi kecil dari alpha $\left(0,01 * * *, 0,05^{* *}\right.$ dan $\left.0,10 *\right)$ maka dapat disimpulkan bahwa variabel independent berpengaruh signifikan terhadap variabel dependent. Sebaliknya jika nilai signifikansi > alpha $\left(0,01 * * *, 0,05 * *\right.$ dan $\left.0,10^{*}\right)$ maka variabel independen tidak mempunyai pengaruh secara signifikan terhadap variabel dependent-nya.

\section{HASIL PENELITIAN DAN PEMBAHASAN}

Analisis deskriptif dalam penelitian ini digunakan untuk mendeskripsikan tentang DER, EPS, PBV, PER, ROE dan Return Saham. Hasil analisis deskriptif dapat diperlihatkan pada tabel 2 berikut ini:

Tabel 2. Descriptif Statistik

\begin{tabular}{lrrrrrrrr}
\hline \multicolumn{1}{c}{ Variabel } & \multicolumn{1}{l}{ Mean } & Median & \multicolumn{1}{l}{ Min } & \multicolumn{1}{l}{ Max } & $\begin{array}{l}\text { Standard } \\
\text { Deviation }\end{array}$ & \multicolumn{2}{l}{$\begin{array}{l}\text { Excess } \\
\text { Kurtosis }\end{array}$} & \multicolumn{1}{c}{ Skewness } \\
\hline DER(x) & $-268,96$ & 43 & $-17.171,03$ & 22.13 & $2,146,34$ & 64,000 & $-8,000$ \\
\hline ROE\% & 10,12 & 215 & $-94,74$ & 57.51 & 18,60 & 17,931 & $-2,287$ \\
\hline PER(X) & 63,96 & 1763 & $-430,52$ & 1,824 & 272.28 & 19,782 & $-1,782$ \\
\hline EPS(Rp) & $1.710,28$ & 51 & -41.496 & 63,926 & $11,426.31$ & 18,353 & 2,586 \\
\hline PBV(X) & 2,79 & 195 & $-108,76$ & 41,00 & 15,94 & 50,673 & $-6,515$ \\
\hline RS\% & 123,13 & & $-99,95$ & $26.85,71$ & 486,28 & 23,177 & 4,800 \\
\hline
\end{tabular}

Sumber : Data Olahan Smart PLS, 2020

Berdasarkan tabel diatas dapat dijelaskan dekkripsi rasio DER pada perusahaan dimana menunjukan nilai rata-rata yang negatif hal ini berarti perusahaan dalam kondisi baik-baik saja, dengan arti kata perusahan masih dapat memenuhi keajibannya dengan menggunkan modalnya. sedangkan secara rata-rata nilai ROE, PER, EPS, PBV serta return saham bahwa perusahaan memperlihatkan nilai yang positif, nilai ini dapat diartikan bahwa perusahaan selama 2012 sampai dengan 2019 yang kondisi baik. Semakin tinggi nilai ROE, PER, EPS, PBV serta return saham berarti perusahaan masih mampu mempertahankan eksistensi dalam menjalankan kegiatan operasional perusahaan untuk meningkatkan kinerja keuangannya.

Uji Collinearity Statistics (VIF) dilakukan dengan melihat nilai multikolinieritas yang baik dalam model regresi $<10$. Jika nilai variabel bebas tersebut $<10$ maka dapat 
dikatakan variabel tersebut layak digunakan dalam pengujian model regresi. Adapun hasil pengujian multikolinieritas dapat diperlihatkan pada tabel 3 dibawah ini:

Tabel 3. Uji Collinearity Statistics (VIF)

\begin{tabular}{cccl}
\hline No & Variabel & VIF & \multicolumn{1}{c}{ Kesimpulan } \\
\hline 1 & DER $(\mathrm{X} 1)$ & 9,922 & Tidak Terjadi Gejala Multikolinieritas \\
\hline 2 & ROE $(\mathrm{X} 5)$ & 1,157 & Tidak Terjadi Gejala Multikolinieritas \\
\hline 3 & PER $(\mathrm{X} 4)$ & 1,064 & Tidak Terjadi Gejala Multikolinieritas \\
\hline 4 & EPS $(\mathrm{X} 2)$ & 1,130 & Tidak Terjadi Gejala Multikolinieritas \\
\hline 5 & PBV $(\mathrm{X} 3)$ & 9,900 & Tidak Terjadi Gejala Multikolinieritas
\end{tabular}

Dependen Variabel : Return Saham

Sumber : Data Olahan Smart PLS, 2020

Berdasarkan hasil pengujian multikolinieritas dalam penelitian ini dapat dijelaskan bahwa seluruh variabel bebas yang digunkan mempunyai nilai $<10$. Hasil penelitian dapat disimpulkan bahwa tidak terjadi multikolonieritas model regresi, sehingga dapat artikan variabel variabel bebas dalam penelitin tidak menunjukan hubungan antara variabel bebas yang satu dengan variabel bebas yang lainnya.

Uji kelayakan Model (R Square) adalah uji yang bertujuan untuk melihat kelayakan model dalam regresi. Model yang baik adalah model yang dapat menjelaskan atau besar pengaruhnya variabel bebas terhadap variabel dependent-nya. Pengujian kelayakan model dapat dilihat salah satunya dari nilai R Square Adjusted. Semakin besar nilai ini maka semakin baik model yang dihasilkan dalam pengujian. Uji kelayakan model penelitian ini disajikan tabel 4 di bawah ini:

Tabel 4. Uji Kelayakan model

\begin{tabular}{cccc}
\hline $\begin{array}{c}\text { Dependent } \\
\text { Variabel }\end{array}$ & Independen Variabel & R Square Adjusted & Kesimpulan \\
\hline RS & DER, EPS, PBV, PER, & $0,278(27,80 \%)$ & Model Layak \\
\hline
\end{tabular}

Sumber : Data Olahan Smart PLS, 2020

Berdasarkan hasil Uji Kelayakan model dijelaskan bahwa nilai R Square Adjusted sebesar 0,278 atau 27,8\%. Nilai ini berarti variabel DER, EPS, PBV, PER, ROE berpengaruh terhadap return saham sebesar $27,8 \%$ sedangkan sisanya sebesar 70,2\% yang tidak dijelaskan dalam model pengujian ini.

Analisis regresi PLS dalam penelitian ini digunakan karena data yang digunakan tidak berdistribusi normal. Hasil pengujian dapat diperlihatkan pada tabel 5. 
Tabel 5. Analisis Regresi PLS dan Uji Hipotesis

\begin{tabular}{cccrc}
\hline Variabel & $\begin{array}{c}\text { Original } \\
\text { Sample }(\mathbf{O})\end{array}$ & $\begin{array}{c}\text { T Statistics } \\
(\mid \text { O/STDEV } \mid)\end{array}$ & P Values & \multicolumn{1}{c}{ Kesimpulan } \\
\hline DER $(x 1)->$ RS & $-0,421$ & 0,560 & 0,576 & Tidak Signifikan \\
\hline ROE $(\mathbf{x} 2)$-> RS & $\mathbf{- 0 , 3 5 4}$ & $\mathbf{1 , 6 9 4}$ & $\mathbf{0 , 0 9 1 *}$ & Signifikan Negatif \\
\hline PER(x3) -> RS & $\mathbf{0 , 5 0 9}$ & $\mathbf{1 , 8 0 8}$ & $\mathbf{0 , 0 7 1 *}$ & Signifikan Positif \\
\hline EPS $(x 4)->$ RS & 0,118 & 0,828 & 0,408 & Tidak Signifikan \\
\hline PBV(x5) -> RS & 0,465 & 0,701 & 0,484 & Tidak Signifikan \\
\hline
\end{tabular}

Catatan ; Jika Signifikansi $<0.10^{*},<0.05^{* *},<0.01^{* * *}$

Sumber : Data Olahan Smart PLS, 2020

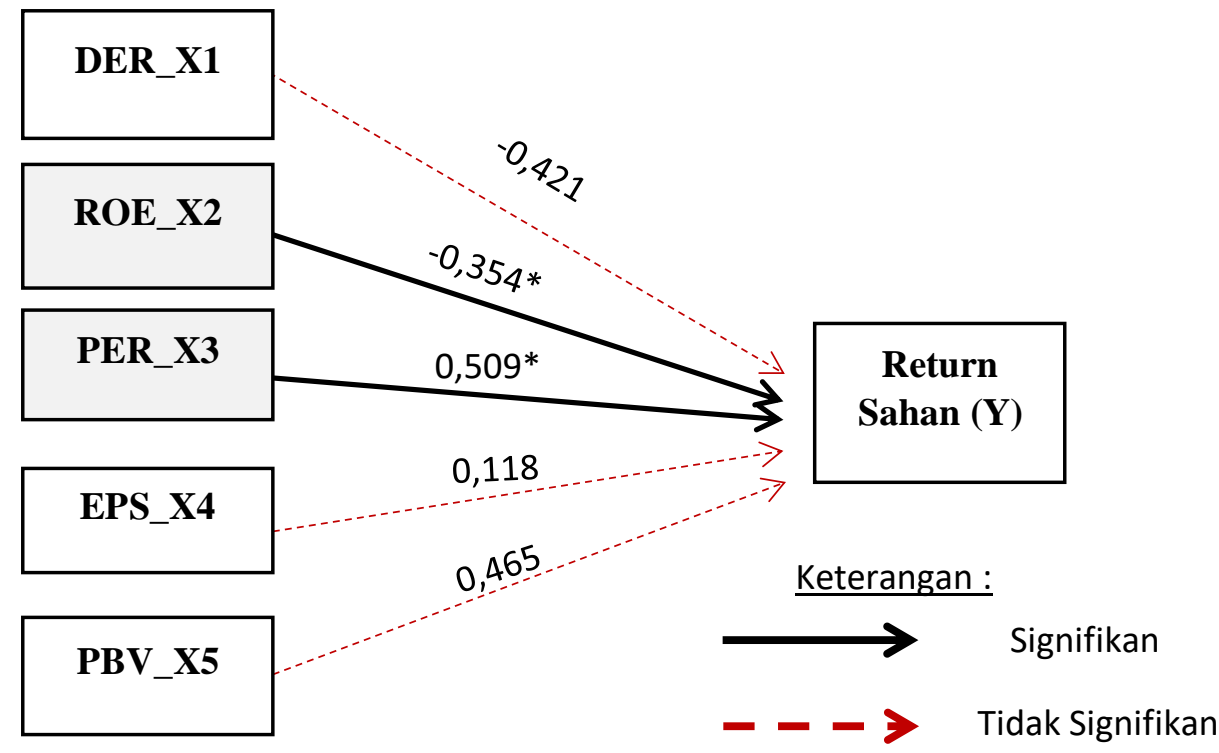

Gambar 2. Model Regresi Linier Berganda

Sumber : Hasil Data Olahan Smart PLS, 2020

Berdasarkan hasil pengujian regresi PLS tersebut maka dapat dibuat suatu persamaan dalam regresi sebagai berikut :

$$
\begin{gathered}
Y=b 1 \times 1+b 2 \times 2+b 3 \times 3+b 4 \times 4+b 5 \times 5 \\
Y_{\text {Return_Saham }}=-0,421_{\text {DER }}-0,354_{\text {ROE }}+0,509_{\text {PER }}+0,118 \text { EPS }+0,465 \text { PBV }
\end{gathered}
$$

Persamaan regresi PLS dapat dijelaskan: (1) Variabel DER berpengaruh negatif sebesar 0,421. Hal ini dapat dijelaskan bahwa jika variabel DER meningkat satu persent (1\%) dengan asumsi menganggap variabel ROE, PER, EPS dan PBV mempunyai nilai nol (0) atau tetap maka variabel DER dapat menurunkan return saham perusahaan sebesar 0,421 atau 42,1\%. (2) Variabel ROE berpengaruh negatif sebesar 0,354. Hal ini dapat dijelaskan bahwa jika variabel ROE meningkat satu persent (1\%) dengan asumsi menganggap variabel DER, PER, EPS dan PBV mempunyai nilai nol (0) atau tetap maka variabel ROE dapat menurunkan return saham perusahaan sebesar 0,354 atau 35,4\% (3) Variabel PER berpengaruh positif sebesar 0,509. Hal ini dapat dijelaskan bahwa jika variabel PER meningkat satu persent (1\%) 
dengan asumsi menganggap variabel DER, ROE, EPS dan PBV mempunyai nilai nol (0) atau tetap maka variabel PER dapat meningkatkan return saham perusahaan sebesar 0,509 atau $50,9 \%$ (4) EPS mempunyai tanda positif 0,118. Hal ini dapat dijelaskan bahwa jika variabel EPS meningkat satu persent (1\%) dengan asumsi menganggap variabel DER, ROE, PER dan PBV mempunyai nilai nol (0) atau tetap maka variabel EPS dapat meningkatkan return saham perusahaan sebesar 0,118 atau 11,8\%. (5) Variabel PBV berpengaruh positif sebesar 0,465. Hal ini dapat dijelaskan bahwa jika variabel PBV meningkat satu persent (1\%) dengan asumsi menganggap variabel DER, ROE, PER dan EPS mempunyai nilai nol (0) atau tetap maka variabel PBV dapat meningkatkan return saham perusahaan sebesar 0,465 atau 46,5\%

Berdasarkan hasil pengujian menggunakan smart PLS untuk menjelaskan pengujian hipotesis dalam penelitian ini dapat di narasikan yaitu (1) Berdasarkan hasil uji t menujukan bahwa variabel DER mempunyai nilai signifikan sebesar 0,576. Hasil ini berarti mempunyai nilai p-value > nilai alpha. Karena nilai p-value > dari alpha yang telah ditentukan maka dapat diartikan bahwa variabel DER tidak signfikan terhadap return saham perusahaan. Hal ini berarti hipotesis yang telah diajukan tidak dapat diterima. (2) Berdasarkan hasil uji t menujukan bahwa variabel ROE mempunyai nilai p-value sebesar 0,091*. Hasil ini berarti mempunyai nilai p-value<alpha. Karena nilai signifikansi < alpha yang telah ditentukan maka dapat diartikan bahwa variabel ROE mempunyai pengaruh yang signfikan terhadap return saham perusahaan. Hal ini berarti hipotesis yang telah diajukan dapat diterima. (3) Berdasarkan hasil uji t menujukan bahwa variabel PER mempunyai nilai p-value sebesar 0,071*. Hasil ini berarti mempunyai nilai $\mathrm{p}$-value<dari nilai alpha. Karena nilai signifikansi < alpha yang telah ditentukan maka dapat diartikan bahwa variabel PER mempunyai pengaruh yang signfikan terhadap return saham perusahaan. Hal ini berarti hipotesis yang telah diajukan dapat diterima. (4) Berdasarkan hasil uji t menujukan bahwa variabel EPS mempunyai nilai p-value > 0,408 Hasil ini berarti mempunyai nilai p-value > dari nilai alpha. Karena nilai signifikansi lebih besar dari alpha yang telah ditentukan maka dapat diartikan bahwa variabel EPS tidak mempunyai pengaruh secara signfikan terhadap return saham perusahaan. Hal ini berarti hipotesis yang telah diajukan tidak dapat diterima atau hipotesis ditolak. (5) Berdasarkan hasil uji t menujukan bahwa variabel PBV mempunyai nilai p-value sebesar 0,484 Hasil ini berarti mempunyai nilai p-value > alpha. Karena nilai p-value> alpha yang telah ditentukan maka dapat diartikan bahwa variabel PBV tidak mempunyai pengaruh yang signfikan terhadap return saham perusahaan. Hal ini berarti hipotesis yang telah diajukan tidak dapat diterima atau hipotesis ditolak. 
Berdasarkan hasil analisis deskriptif dan hasil uji statistic dengan software smart PLS dapat dilakukan sutu pembahasan yaitu (1) Pengaruh DER terhadap return saham perusahaan kesehatan dan farmasi yang terdaftar pada BEI dimana Rasio DER merupakan rasio yang mengambarkan kemampuan perusahaan dalam melunasi kewajiban atau hutangnya dengan menggunkan asset yang dimiliki perusahaan. Semakin besar nilai rasio ini maka dapat diyakini kinerja perusahaan akan semakin turun, sebaliknya jika nilai rasio ini rendah maka dapat meningkatkan kinerja keuangan perusahaan. Rasio der mempunyai hubungan negative terhadap return saham artinya jika semakin besar rasio ini maka dapat menurunkan return saham perusahan begitu juga sebaliknya jika semakin rendah rasio ini maka perusahaan akan semakin mampu meningkatkan return sahamnya. Berdasarkan hasil uji analisis deskriptif menunjukan bahwa rata-rata DER adalah negative. Hal ini berarti kondisi perusahaan kesehatan dan farmasi yang terdaftar pada BEI sudah cukup baik, artinya perusahaan masih mampu membayar kewajibannya atau hutangnya dengan asset-aset yang dimiliki. Hal ini didukung atau sejalan dengan hasil uji regresi linier berganda bahwa rasio DER perusahaan mempunyai hubungan negatif terhadap return saham perusahan. Hasil ini dapat mengambarkan bahwa DER mempunyai pengaruh negatif terhadap return saham perusahaan.

Kemudian berbeda dengan hasil uji t dapat ditunjukan variabel DER tidak mempunyai pengaruh secara signifikan return saham perusahaan kesehatan dan farmasi yang terdaftar pada BEI. Hal ini berarti hipotesis yang telah diajukan ditolak. Hasil ini mengambarkan bahwa besar atau kecilnya nilai DER perusahan tidak berdampak secara langsung pada peningkatan maupun penurunan return sahaam perusahaan, atau tidak selamanya DER yang rendah dapat meningkatkan return saham perusahaan kesehatan dan farmasi yang terdaftar pada BEI. Hasil pembahasan ini didukung dengan hasil penelitian yang dilakukan Nurfadillah (2011) dan Utami \& Darmawan (2019), dimana hasil penelitiannya menunjukan DER tidak signifikan terhadap return saham. Tetapi bertolak belakang dengan penelitian yang dilakukan Haryanti \& Murtiasih (2019), Amanda et al. (2013) dan Akbar (2015). Hasil penelitiannya memperlihatkan DER signifikan negatif terhadap return saham. Penolakan hasil tersebut juga didukung dengan hasil penelitian oleh Nurfadillah (2011) dan Utami \& Darmawan (2019) DER signifikan positif terhadap return saham. (2) Pengaruh ROE terhadap Return Saham perusahaan kesehatan dan farmasi yang terdaftar pada BEI, dimana Rasio Return on Equity (ROE) merupakan bagian dari rasio profitability, dimana rasio ini mengambarkan kemampuan perusahaan dalam mendapat laba dengan memanfaatkann atau menggunkan modalnya. Dimana semakin besar rasio ini maka semakin baik kinerja keuangan perusahaan. Sebaliknya jika semakin kecil rasio ini maka semakin turun kinerja perusahaan. Rasio ROE 
mempunyai hubungan yang positif terhadap return saham perusahaan, dimana semakin besar rasio ROE ini maka dapat meningkatkan return saham perusahan artinya rasio roe merupakan salah satu faktor penentu yang berfungsi untuk meningkatkan return saham perusahaan. Berdasarkan hasil pengujian secara deskriptif rasio ROE perusahaan mempunyai nilai ratarata positif.

Nilai ini menunjukan kondisi perusahaan perusahaan kesehatan dan farmasi yang terdaftar pada BEI dalam kondisi yang baik. Namun berbeda dengan hasil uji regresi linier berganda menggunkan smart PLS justru Variabel ROE mempunyai hubungan atau berpengaruh negatif terhdap return saham perusahaan. sedangkan hasil uji t menujukan bahwa variabel ROE mempunyai pengaruh secara signifikan terhadap return saham perusahaan. Hal ini berarti hipotesis yang telah diajukan dapat diterima. Hasil ini dapat diartikan bahwa rasio ROE merupakan salah satu rasio yang menjadi faktor penentu dalam meningkatkan atau menurunkan return saham perusahaan kesehatan dan farmasi yang terdaftar pada BEI. Jika semakin tinggi rasio ini maka akan semakin tinggi pula return saham yang diperoleh perusahaan. Karena hasil koefisien regresi negatif berati tingginya nilai rasio ROE justru tidak dapat meningkatkan atau justru menurunkan return saham perusahaan kesehatan dan farmasi yang terdaftar pada BEI. Maka dindikasikan bahwa tidak selamanya ROE yang tinggi dapat meningkatkan return saham parusahaan. Hasil pembahasan ini bertolak belakang dengan hasil yang dilakukan oleh Nurfadillah (2011), Amanda (2013), Smith dan, \& Azis (2016) serta Cahyaningrum \& Antikasari(2017). Hasil penelitiannya menyatakan ROE signifikan positif terhadap return saham. Selanjutnya juga bertolak belakang dengan penelitian yang dilakukan oleh Pratiwi et al. (2016), Utami \& Darmawan (2019) serta Arslan \& Zaman (2014) tidak signifikan terhadap return saham. (3) Pengaruh PER terhadap Return Saham perusahaan kesehatan dan farmasi yang terdaftar pada BEI, Rasio PER merupakan perbandingan antara harga perlembar saham dengan jumlah saham yang beredar.

PER mempunyai peran penting bagi perusahaan, karena tingkat pendapatan perusahaan yang tercermin dari PER yang berhubungan erat dengan tingkat harga saham. Apabila fluktuasi PER semakin tinggi maka Semakin tinggi pula perubahan harga sahamnya dan return sahamnya. Hasil deskriptif menunjukan secara rata-rata nilai PER menunjukan bahwa perusahaan memperlihatkan nilai yang positif, nilai ini dapat diartikan bahwa perusahaan kesehatan dan farmasi yang terdaftar pada BEI dalam kurun waktu 2012 sampai dengan 2019 yang kondisi baik. Semakin tinggi nilai PER berarti perusahaan masih mampu mempertahankan eksistensi dalam menjalankan kegiatan operasional perusahaan untuk meningkatkan kinerja keuangnnya. Hasil uji koefisien regresi PLS menunjukan PER 
mempunyai pengaruh positif terhadap return saham perusahaan. Hasil uji secara pasrial juga dapat diperlihatkan PER tidak berpengaruh secara signifikansi terhadap return saham perusahaan. Hal ini berarti hipotesis yang telah diajukan dapat diterima. Hasil ini dapat dijelaskan bahwa nilai PER perusahan yang tinggi tidak ada jaminan atau tidak selamanya dapat meningkatkan atau menurunnya return saham perusahaan kesehatan dan farmasi yang terdaftar pada BEI dalam kurun waktu 2012 sampai dengan 2019. Hasil ini sejalan dengan penelitian yang dilakukan oleh Amanda et al. (2013) dan Akbar (2015) hasil penelitiannya mengungkapakan bahwa PER tidak signifikan terhadap return saham. Tetapi hasil tersebut bertolak belakang dengan hasil penelitian yang dilakukan oleh Suharno (2016), Herawati \& Putra (2018), serta Imran \& Shahzad (2014) hasil penelitiannya menyatakan bahwa PER signifikan positif terhadap return saham. (4) Pengaruh EPS terhadap Return Saham perusahaan kesehatan dan farmasi yang terdaftar pada BEI, Earning Per Share penting bagi perusahaan digunakan untuk menggambarkan jumlah rupiah yang diperoleh untuk setiap lembar saham biasa.

EPS mempunyai hubungan positif terhadap return saham perusahaan. Jika EPS perusahaan meningkat maka Return saham akan meningkat. Berdasarkan hasil pengujian secara deskriptif rasio EPS perusahaan mempunyai nilai rata-rata positif. Nilai ini menunjukan kondisi perusahaan dalam kondisi yang baik. Dapat ditunjukan hasil uji koefisen regresi pls bahwa EPS mempunyai hubungan atau pengaruh positif terhadap return saham perusahaan. Hasil uji secara parsial dapat ditunjukan EPS tidak mempunyai pengaruh secara signfikan terhadap return saham perusahaan. Hasil ini dapat disimpulkan tidak selamanya EPS yang tinggi dapat meningkatkan return saham perusahaan kesehatan dan farmasi yang terdaftar pada BEI dalam kurun waktu selama 2012 sampai dengan 2019. Hasil ini sejalan dengan Ahmed (2018) dimana hasil penelitianya mengatakan EPS tidak signifikan terhadap return saham. Tetapi bertolak belakang dengan hasil penelitian yang dilakukan oleh Nurfadillah (2011), Pratiwi et al. (2016), Amanda et al. (2013), Utami \& Darmawan (2019), Haryanti \& Murtiasih (2019), Arslan \& Zaman (2014) Suyono dan yoki (2018) serta Cahyaningrum \& Antikasari (2017) hasil penelitiannya menyatakan PER signifikan positif terhadap return saham. (5) Pengaruh PBV terhadap Return Saham Perusahaan sub sektor kesehatan dan farmasi yang terdaftar di Bursa Efek Indonesia, Price Book Value (PBV) menunjukan seberapa mempu menciptakan nilai perusahaan rrelatif terhadap jumlah modal yang diinvestasikan. PBV mempunyai hubungan atau pengaruh positif terhadap return saham, dimana semakin besar nilai PBV maka akan semakin tinggi nilai saham perusahaan. Berdasarkan hasil pengujian secara deskriptif rasio PBV perusahaan mempunyai nilai rata- 
rata positif. Nilai ini menunjukan kondisi perusahaan dalam kondisi yang baik untuk meningkatkan kinerja keuangan perusahaan. Hasil uji koefisen regresi PLS menunjukan PBV berpengaruh positif return saham perusahaan. Tetapi Berdasarkan hasil uji parsial menujukan bahwa variabel PBV tidak mempunyai pengaruh yang signfikan terhadap return saham perusahaan. Hal ini berarti tingga rendahnya PB tidak menjadi faktor pemicu return saham perusahaan kesehatan dan farmasi yang terdaftar pada BEI dalam kurun waktu 2012 sampai dengan 2019. Hasil pembahasan ini sejalan dengan penelitian yang dilakukan oleh Akbar (2015) hasil penelitiannya menyatakan bahwa PBV tidak signifikan terhadap return saham. Hasil ini berarti bertolak belakang dengan hasil yang dilakukan oleh Cahyaningrum \& Antikasari (2017). Penolakan ini juga didukung dengan penelitian yang dilakukan oleh Benazir (2016) PBV signifikan negatif terhadap return saham perusahaan.

Hubungan fenomena dengan hasil penelitian: Jika melihat kondisi fenomena yang terjadi perusahaan kesehatan dan farmasi yang terdaftar pada BEI selama periode pengamatan 2012 sampai dengan 2019 kondisi indeks harga saham menunjukan berfluktuasi, hal ini tentu banyak pemicu kondoi tersebut salah satunya diantaranya faktor DER, ROE, PER, EPS dan PBV. Tetapi bedasarkan hasil pengamatan yang telah dilakuna dengan cara menguji variabel variabel ttersebut terhadap retusn sahan hasil dugaan memang benar bahwa indeks harga saham perusahaan kesehatan dan farmasi yang terdaftar pada BEI selama periode 2012 sampai dengan 2019 berfluktuatif disebabkan oleh faktor Return On Equity (ROE) dan Price Earning Ratio (PER), karena hasil penelitian membuktikan bahwa ROE dan PER berpengaruh secara signifikan terhadap return saham perusahaan. Tetapi variabel DER, EPS dan PBV justru tidak benar yang menjadi faktor penentu atau penyebab naik atau turunnya indeks harga saham perusahaan kesehatan dan farmasi yang terdaftar pada BEI selama periode pengamatan 2012 samapi dengan 2019, karena hasil penelitian membuktikan variabel DER, EPS dan PBV tidak mempunyai hubungan tau pengaruh terhadap return saham perusahaan-perusahaan perusahaan kesehatan dan farmasi yang terdaftar pada BEI selama periode pengamatan 2012 sampai dengan 2019.

\section{KESIMPULAN DAN SARAN}

Didasarkan pada hasil pengujian, maka dapat dibuat suatu kesimpulan dalam penelitian ini yaitu (1) variabel DER tidak signfikan terhadap return saham perusahaan. Hal ini berarti hipotesis yang telah diajukan tidak dapat diterima. (2) variabel ROE mempunyai pengaruh yang signfikan terhadap return saham perusahaan. Hal ini berarti hipotesis yang telah diajukan dapat diterima. (3) Variabel PER mempunyai pengaruh yang signfikan terhadap 
return saham perusahaan. Hal ini berarti hipotesis yang telah diajukan dapat diterima. (4) variabel EPS tidak mempunyai pengaruh secara signfikan terhadap return saham perusahaan. Hal ini berarti hipotesis yang telah diajukan tidak dapat diterima atau hipotesis ditolak. (5) variabel PBV tidak mempunyai pengaruh yang signfikan terhadap return saham perusahaan. Hal ini berarti hipotesis yang telah diajukan tidak dapat diterima atau hipotesis ditolak. Merujuk pada kesimpulan dalam penelitian ini maka dapat dibuat saran kepada (1) bagi perusahaan agar melihat faktor ROE dan PER, karena hasil penelitian membuktikan bahwa rasio tersebut mempunyai pengaruh atau menjadi faktor penentu terhadap return saham. (2) bagi investor, jika ingin melakukan keputusan berinvestasi pada perusahaan kesehatan dan farmasi yang terdaftar pada BEI juga perlu mempertimbangkan rasio ROE dan PER karena besar atau kecilnya return saham ditentukan oleh kedua rasio tersebut. (3) bagi peneliti selanjutnya agar kiranya menambah dan menganti variabel yang tidak mempunyai kontribusi terhadap return saham dengan variabel variabel yang lainnya, sehingga dapat menemukan model penentu untuk return saham perusahaan kesehatan dan farmasi yang terdaftar pada BEI selama periode penelitian 2012 sampai dengan 2019.

\section{REFERENSI}

Ahmed, I. (2018). Impact Of Dividend Per Share and Earnings Per Share On Stock Prices: A Case Study From Pakistan (Textile Sector). IJSSHE-International Journal of Social Sciences, Humanities and Education Volume, 2(2).

Athanasius Thomas. (2012). Panduan Berinvestasi Saham. Elex Media Komputindo

Akbar, R. (2015). Analisis Pengaruh DER, PBV dan PER terhadap Return Saham Perusahaan Manufaktur yang Terdaftar di Bursa Efek Indonesia Periode 2008 - 2012 (Studi Kasus pada Perusahaan dalam Kategori Consumer Goods Industry, Food And Beverages, Tobacco Manufactur, JESTT, 2(9), 1689-1699. https://doi.org/10.1017/CBO9781107415324.004

Amanda A, et al. (2013). Pengaruh Debt To Equity Ratio, Return On Equity, Earning Per Share, dan Price Earning Ratio terhadap Harga Saham (Studi pada Perusahaan Food and Beverages yang Terdaftar di BEI Tahun 2008-2011). Jurnal Administrasi Bisnis S1 Universitas Brawijaya, 4(2), 75435.

Arslan, M., \& Zaman, R. (2014). Impact of Dividend Yield and Price Earnings Ratio on Stock Returns: A Study Non-Financial listed Firms of Pakistan. Research Journal of Finance and Accounting, 5(19), 2222-2847.

Benazir, M. S. A. M. and. (2016). An Indirect Impact of the Price to Book Value to the Stock Returns: An Empirical Evidence from the Property Companies in Indonesia. Jurnal Akuntansi Dan Keuangan, 17(2), 91-96. https://doi.org/10.9744/jak.17.2.91-96

Cahyaningrum, Y. W., \& Antikasari, T. W. (2017). Pengaruh Earning Per Share, Price To Book Value, Return on Asset, Dan Return on Equity Terhadap Harga Saham Sektor Keuangan. Jurnal Economia, 13(2), 191. https://doi.org/10.21831/economia.v13i2.13961 Damodaran, Aswath. (2012).Investment Valuation. New Jersey: John Wiley \& Sons Fahmi, I.(2013). Analisis Laporan Keuangan. Bandung: Alfabeta, 2010-2011. 
Ghozali, I. (2016). Aplikasi Analisis Multivariate dengan Program SPSS. Semarang: UNDIP.

Haryanti, Y., \& Murtiasih, S. (2019). The Effects of DER, ROA and DPR on Stock Price with EPS as the Moderating Variable in SOE. IOSR Journal of Business and Management (IOSR-JBM), 21(7), 1-08. https://doi.org/10.9790/487X-2107040108

Herawati, A., \& Putra, A. S. (2018). The influence of fundamental analysis on stock prices: The case of food and beverage industries. European Research Studies Journal, 21(3), 316-326. https://doi.org/10.35808/ersj/1063

Imran, A., \& Shahzad, M. (2014). Munich Personal RePEc Archive Impact of Dividend Policy, Earning per Share, Return on Equity, Profit after Tax on Stock Prices PhD Scholar, National College of Business Administration. Internasional Jurnal of Economic and Empirical Research, 2(3), 109-115.

Karnadjaja, Agustino. (2009). Smart Investment for Mega Profit. Jakarta: PT. Elex Media Komputindo.

Nurfadillah, M. (2011). Analisis Pengaruh Earning Per Share, Debt To Equity Ratio Dan Return On Equity terhadap Harga Saham PT Unilever Indonesia Tbk. Jurnal Manajemen Dan Akuntansi, 12(4), 45-50.

Pratiwi, Ni Putu Yuni, et al. (2016). Struktur Modal terhadap Nilai Perusahaan. Journal of Management and Business, 4. https://doi.org/10.24123/jmb.v7i1.122

Ross, A Stephen. Westerfield, Randolph W. Jordan, Bradford D. (2003). Fundamentals of Corporate Finance. Sixth edition. NewYork: Mc Graw-Hill.

Smith, M. dan, \& Azis, F. T. R. (2016). Pengaruh Dividend Per Share (DPS) dan Return On Equity (ROE) terhadap Harga Saham pada Perusahaan Indeks Lq45 yang Terdaftar di Bursa Efek Indonesia (BEI). Jurnal Studia Akuntansi Dan Bisnis, 5(2), 71-78.

Suharno. (2016). Pengaruh Rasio Keuangan terhadap Harga Saham Perusahaan Farmasi yang Terdaftar di Bursa Efek Indonesia Tahun 2010- the Effect of the Financial Ratio on the Prices of the Stocks of. Jurnal Pendidikan Dan Ekonomi, 301-307.

Syamsuddin, Lukman. (2011). Manajemen Keuangan Perusahaan: Konsep Aplikasi dalam Perencanaan, Pengawasan, dan Pengambilan Keputusan. Jakarta: PT.Raja Grafindo Persada

Suyono.Yoki. (2018). Analisis Pengaruh Rasio Fundamental terhadap Harga Saham pada Perusahaan Transportasi Terdaftar di BEI Periode 2011-2016. Kurs: Jurnal Akuntansi, Kewirausahaan dan Bisnis, 3(1), 89-100

Utami, M. R., \& Darmawan, A. (2019). Effect of DER, ROA, ROE, EPS and MVA on Stock Prices in Sharia Indonesian Stock Index. Journal Of Applaied Accounting and Taxation, 4(1), 15-22.

Widayanti, R., Ekawati, H., Dorkas, A., Rita, M. R., dan Sucahyo, U. S. (2009). Manajemen Keuangan. Edisi Revisi. Salatiga: Fakultas Ekonomi UKSW

www.idx.co.id Diakses Pada Tanggal 17 Januari tahun 2020

www.sahamok.com diakses pada Tanggal 10 Januari tahun 2020

www.yahoofinance.com diakses Pada Tanggal 20 Januari tahun 2020 